\title{
Potato (Solanum tuberosum L.) technology development and promotion for sustainable food security and commercialization in Awi zone, Northwestern Ethiopia
}

Addisu Getahun ( $\sim$ addisugetahun2004@gmail.com )

Injibara University https://orcid.org/0000-0002-2187-0967

\section{Method Article}

Keywords: Potato, Injibara University, Cultivar development, Fertilizer recommendation, SAS Ver.9, Pest management, Technology transfer

Posted Date: May 26th, 2021

DOI: https://doi.org/10.21203/rs.3.rs-563895/v1

License: (c) (1) This work is licensed under a Creative Commons Attribution 4.0 International License. Read Full License 


\section{Abstract}

Potato is one of the most important highland crops that highly contribute to food security in different parts of Ethiopia as well as in the world. A major constraint for potato production and productivity includes lack of high yielding varieties, low soil fertility, poor crop management practice, drought, Insect pest, diseases, weeds, poor post-harvest handling techniques, and poor linkages of value chain actors, low dry matter and starch content. The major objectives of this project are to introduce best-performed genotypes with good pest resistance, improve potato cultivation techniques with appropriate agronomic practices, to identify and manage major pests of potato and their effects on yield loss, analyses potato value chain actors and production economics, evaluate post-harvest handling of potato. The project will be carried out using different experimental designs (Randomized Complete Block Design, split plot, lattice arrangement, single plot), sampling methods (random and systematic sampling techniques), both qualitative and quantitative data will be collected and analysed using different statistical software packages (SAS, SPSS, Genstat, PBTools).

\section{Introduction}

Potato (Solanum tuberosum L.) is the fourth most important food crop next to rice, wheat, and maize, and has a great contribution to food and nutrition security in the world [1]. In Sub-Sahara Africa, potato is a steadily growing demand a trend that is expected to continue [2]. It is a crop that can be used to improve food security and cash income in Ethiopia due to its high yield per unit area, presence of suitable agroecological zones within the country, the availability of labor for its production on large areas of land, economic development from small areas and the accessibility of a potential market with considerable added value for its produce [3]. During 2015/16 cropping season land coverage of potato was 70131.32 ha, 22793.57 ha and 3088.48 ha in Ethiopia, Amhara region and Awi zone respectively [4]. According to FAO [5], In Ethiopia area under potato cultivation was about 51,698 ha in 2005/6 cropping season that produced 509,716 tons of tuber yields while, in 2014/2015, area under potato crop has increased to 67,362 ha and its total production was 921,832 tones. However, the national productivity is $13.7 \mathrm{t}$ ha- 1 in the production years of 2014/2015 [5] which is still far less than that of other countries. Many factors that contribute to the low yield of potato are; drought [6, 7]), frost, hail, pests [8], poor production practices and limited access to high quality seed $[9,10]$.

Genotypic variation and relatively short vegetative period allows farmers to find an appropriate season for its cultivation under a wide range of weather patterns and less predictable climates. Ethiopian potato research, system has released 31 new potato varieties to address some of these production problems [11] but in Awi zone there is a limitation of high yielding, pest resistant and high nutritional quality improved varieties. Ethiopia's tremendous variation in altitude, temperature, rainfall, soil type, and ecological settings gives rise to the need for a wide range of varieties, which are not likely to be provided by existing breeding programs [12]. 
According to EARO [13], Love and [14 \& 15] the declining of potato productivity is poor agronomic practices for instance; use of low fertilizers inputs, inappropriate planting depth, poor earthing up, and poor management of cropping system.

The other causes for the reduction of production and productivity of potato are biotic constraints, such as pests (diseases, insect pests and weeds) are the major constraint for potato production. According to [16] bacterial wilt, potato late blight, aphids and tuber moth are the major pests of potato, in addition to disease and insect pests weed has also cause of heavy yield loss in the major crops with an average of $25-32 \%[17]$.

Production is the key activity in agricultural value chain. The value chain network functioning around smallholder farmers comprises linkage among input suppliers, farmers, co-operatives, extension service providers, credit service providers, and traders. Farmers face a series of challenges that limit their overall production and income [18]. Furthermore, despite the potential from potato farming and significant gap on productivity and marketing of potato in Ethiopia, an increase production does not necessarily have to lead to an increase in marketable surplus. An interesting issue in this regard is what factors determine the farmers to participate in the potato market. In general, there is inadequate research works done on value chain analysis of potato in Ethiopia in general and the study area in particular. Hence, this study is motivated to identify value chain actors, their roles and their value addition, to identify factors affecting the level of production and analyze determinants of small-scale farmer's participation decisions and level of participation in potato market.

\section{Objectives}

\section{General objective:}

- To develop and promote new improved technologies of potato for sustainable production, productivity and commercialization thereby contributes to sustainable food security and adapt to climate change across different agro-ecologies of northwestern Amhara region.

\section{Specific objectives:}

1. To develop stable, high yielding varieties with acceptable quality that meet different market standards and tolerant/resistant to biotic and abiotic stresses prevailing in major potato growing regions of awi zone.

2. To develop appropriate agronomic practices and enhancing soil fertility for potato production and productivity

3. To identify major potato pests, their loss and develop management measures

4. To demonstrate, popularize, multiply and promote improved technologies of potato including food recipes and post-harvest handling mechanisms 
5. To analyze value chain and production economics, adoption and impact of improved technologies for major production areas.

\section{Materials And Methods}

\section{Description of the Project}

This mega project proposal has organized from four major components (research divisions). The main components include cultivar development for high yielding and different maturity groups, crop management and cropping systems, pest management, and socio-economic studies.

\section{Description of the project area}

The study will be conducted in Awi zone, Amhara national region, Ethiopia, particularly in major potato producing areas during the main growing season or under irrigation in 2018/19. Awi zone is situated between $10^{\circ} 23^{\prime} \mathrm{N}$ and $10^{\circ} 85^{\prime} \mathrm{N}$ latitude and $36^{\circ} 35^{\prime} \mathrm{E}$ and $36^{\circ} 57^{\prime} \mathrm{E}$ longitude with an altitude range between 1800-3100 masl. It has a mean annual rainfall of $1750 \mathrm{~mm}$ and a mean monthly temperature ranges from $17-27^{\circ} \mathrm{C}$.

\section{Component 1: Cultivar Development \& Improvement}

Objective - To develop stable, high yielding cultivars with acceptable quality that meet consumers interest, full fill market needs, and resistant to biotic and abiotic stresses prevailing in major potato growing areas.

\section{Specific Objectives}

- To identify superior genotypes for further breeding programs and yield evaluation.

- To estimate genetic variability and heritability between genotypes across environments.

Activity: 1 Estimation of Phenotypic, genetic variability and heritability of potato genotypes in awi zone.

\section{Methodology:}

- Design : RCBD/ Alpha lattice with three replications

- Treatment:16-100 genotypes

- Data to be collected : All important agronomic data will be collected

- Data analysis: ANOVA, PCA (principal component analysis), path coefficient analysis, cluster analysis and others will be done for both qualitative and quantitative data using SAS 9.4 version and other appropriate software packages.

- Location: Banja, Dangla, Guagusa shukudad, Guangua

- Duration: 2019-2020 
Activity 2: Variety adaptation trial for high yielding, resistant to major diseases and insect pests in potato growing areas.

\section{Methodology:}

- Design: Lattice/RCBD with three replications

- Treatment:25-81elite genotypes will be tested

- Data to be collected: all important quantitative yield and yield component data will be collected

- Data analysis: SAS/PBTools/Genstat (use new version)

- Location: Banja, Dangla, Chagni

- Duration: 2019-2020

Activity 3: Potato germplasm acquisition for cultivar development and improvement for different purpose (high carbohydrate content, high starch content, high yield, for major pest resistance, low $\mathrm{N}$ and $\mathrm{P}$ and drought tolerant.)

\section{Methodology}

- Design: Alpha lattice with three replications of checks

- Treatments: 20-50 genotypes

- Data to be collected: all important quantitative yield and yield related trait data will be collected

- Data analysis: SAS ver. 9.4

- Location: Banja, Guangua, Dangla, Fagita lekoma, Guagusa shukuda

- Duration: 2019 - 2021

\section{Component: 2 Crop Management}

Objective-To develop appropriate agronomic practices and enhancing soil fertility for potato production and productivity.

\section{Specific objectives:}

1. To evaluate the growth, nutrient uptake and yield response of potato to different inorganic, organic fertilizers rates application and recommend.

2. To amended soil and increase soil fertility in the study area.

3. To evaluate the economic feasibility of the fertilizers

4. To determine planting depth and frequency of earthing up of potato on yield and yield related traits Activity1:-Response of potato growth, yield and yield related traits to blended fertilizer application.

\section{Methodology}


- Design: factorial RCBD with three replications

- Treatments: 25(4 improved and 1 local varities, Fertilizers NPS, NPSB, NPSZnB $(0,100,150 \mathrm{~kg} / \mathrm{ha}$, $200 \mathrm{~kg} / \mathrm{ha}, 225 \mathrm{~kg} / \mathrm{ha}$ ), Varieties (Belete, Jalene, Kulumsa, Digemegn , local

- Data to be collected: The representative composite soil sample will be taken at a depth of 0-20 cm from five randomly selected spots diagonally across the experimental field-using auger before planting and residual soil will be taken

- Data analysis: SAS (use version 9.4)

- Location: Awi zone

- Duration: 2019-2020(two consecutive cultivating seasons)

Activity 2:-Response of integrated application of biochar and fertilizer rate on yield and yield traits of potato

\section{Methodology}

- Design: RCBD with three replications

- Treatment combinations: Five NPS fertilizer rates $(0,50,100 \mathrm{~kg} / \mathrm{ha} ., 150 \mathrm{~kg} / \mathrm{ha}, 200 \mathrm{~kg} / \mathrm{ha})$ based on agricultural transformation agency tentative fertilizer recommendation rate on the study area $(100 \mathrm{~kg}$ $\mathrm{ha}^{-1}$ NPS blended fertilizer was tentative recommendation) and Biochar ( 0 ton/ha,5ton/ha. 10ton//ha, 15ton/ha,20 ton/ha,)

- Data to be collected: all important quantitative yield and yield related trait data will be collected

- Data analysis: SAS Ver. 9.4

- Location: Awi zone

- Duration: 2019-2020 (two consecutive cultivating seasons)

Activity 3:-Effect of manure and lime application on potato yield traits and soil fertility

\section{Methodology}

- Design: factorial RCBD with three replications

- Treatment: 20 (manure:-0, 5, 10,15, 20 ton ha-1 lime:- 0, 2, 4, 6 ton ha-1)

- Duration: 2019-2020

- Location: Awi zone

Activity 4:- Effect of earthing up frequencies and planting depth on yield traits and yield of potato

\section{Methodology}

- Design: Factorial RCBD with three replications 
- Treatment: 15 (Planting depth:- three level $\mathrm{cm}, 5 \mathrm{~cm}, 10 \mathrm{~cm}, 15 \mathrm{~cm}$ and earthing up 0,1times,2 times,3 times, 4 times level. The seed tubers seeding depth recommendation were $5 \mathrm{~cm}$ in the soil [19] at the spacing of $75 \mathrm{~cm}$ between rows and $30 \mathrm{~cm}$ between seed tubers.

- Data will be collected: different growth and yield components data will be recorded on sample plants on plot basis.

- Phonological data: Days to $50 \%$ emergency, days to flowering and days to $90 \%$ maturity

- Growth parameters: Plant height and main stems number per hill

- Yield and yield components: Marketable tuber number per hill: [20] , unmarketable tuber number per hill:- [20] ,total tuber Number per hill [21], Marketable tuber yield (ton per ha: [21], unmarketable tuber yield (ton per ha): The average weight of tubers, which were unhealthy, injured by insect pests, with defects and less than $25 \mathrm{~g}$ weight category from net plots tubers will be recorded and calculated to $t$ ha-, Total Tuber Yield (ton/ha): [21]. Dry matter content of tuber (\%): Five potato tubers will be randomly selected from each plot, chopped into small $1-2 \mathrm{~cm}$, mixed thoroughly, and two subsamples each weighing $200 \mathrm{~g}$ will be weighed. The exact weight of each sub-sample will be determined and recorded as fresh weight. Each sub-sample will be placed in a paper bag and put in an oven at $70^{\circ} \mathrm{C}$ until a constant dry weight will be attained. The sample will be immediately weighed and recorded as dry weight. Percent dry matter content will be calculated based on the formula described by Bonier bale et al. [22].

Dry matter $(\%)=\underline{w e i g h t} \underline{\text { ofsample after }}$ drying $($ ga $) \times 100$

\section{Initial weight of sample (g)}

Specific Gravity of Tubers ( $\mathrm{gcm}-3$ ): Tubers of all size categories weighing about five kilogram will be randomly taken from each plot and washed with water. Following this step, the sample will be first weighed in air and then re-weighed suspended in water. Specific gravity will be finally determined as described by Kleinkopf et al. [23].

Specific gravity $\left(\mathrm{g} \mathrm{cm}^{-3}\right)=\quad$ Weight of tubers in air

\section{Weight of tubers in air - Weight of tubers in water}

Data analysis: using the GLM SAS [24] procedure. Mean separation values will be separated by using Duncan's multiple range test (DMRT).

Partial budget analysis will be done based on the procedure described by CIMMYT (1988) [25].

Duration: - 2019-2020 cropping season.

Location: -Awi zone

Component 3: Pest Management

Page $7 / 12$ 
Objective: To identify major potato pests, their loss and develop management measures

\section{Specific objective:}

- To identify major pest of potato and their losses in the study area.

- To design management options for major pests of potato.

Activity 1: Identification of major pests of potato, their loss and develop the control measures in Awi zone north western Ethiopia.

\section{Methodology}

Sampling techniques: Major potato producing areas of Awi zone will be selected purposefully. Six potato producer districts will be selected and from each district five potato producing Kebele will be surveyed and 150 fields will be assessed. Weed experiment will consist 16 treatments (a combination of 3 preemergent herbicides, two physical weed control, two potato variety, weedy and weed free check for each variety) will randomly arranged in RCBD with three replications. The experiment for biological control of insect pest will be consisted 9 treatments (a combination of 3 parasitoids, 3 predators and 3 botanical extracts) will randomly arranged in a complete randomized design (CRD) with three replications.

Data to be collected: Disease incidence, severity and prevalence, for insect data insects pests species, number of nymph, number of adult, predator, parasitoid and for weed data weed species, weed density, weed species richness, field uniformity, frequency percentage, weed dry weight, days to $90 \%$ emergence, $50 \%$ flowering, $90 \%$ physiological maturity, plant height, number of tubers per ridge, above ground dry biomass, tuber yield and harvest index will be recorded.

Data Analysis: The survey data will be analyzed using SPSS version 20th software, laboratory and field data will be analyzed using Gene stat software version $16^{\text {th }}$.

Duration: - 2019-2021.

Location: -Awi zone

\section{Component: 4 Socio-economic Studies}

Objective: To analyze socio-economic aspects and status of potato in major production areas of Awi zone.

\section{Activity 1: Value chain analysis of potato}

\section{Specific objectives:}

- To identify value chain actors, their roles and their value addition in the potato value chain;

- To identify factors affecting the level of production of potato in the study area 
- To analyze factor affecting the smallholders market participation decisions and level of participation in potato market.

- To measure the level of technical efficiency in the production of potato in the study area

- To identify factors that determines technical efficiency of potato producing households in the study area

- To assess the influence of agro ecological zone on technical inefficiency of potato production

\section{Methodology}

- Preparation and pre-testing of questionnaire

- Mixed Research design (Case study and exploratory research design)

- Sampling (multistage random sampling method, for producers and purposive for other potato value chain actors)

- Secondary data collection

- Method of data collection: questionnaire key informant interview and Focus Group Discussion (FGD).

- Data analysis: the collected data will be analyzed by using STATA software (data required descriptive statistics and econometrics model, value chain analysis tool, market margin analysis formulas, and heckman two stage model)

- Location: Three representative districts of awi zone

- Duration: 2019-2020

Activity 2: Technology adoption and impact assessment study

\section{Methodology}

- On station and farmers selection and sampling

- Preparation and pre-testing of questionnaire

- Sampling: multistage random sampling methods

Data collection: both primary and secondary data will be collected

- Method of data collection: questionnaires key informant interview and Focus Group Discussion (FGD).

- Data analysis: the collected data will be analyzed by using STATA software (data required descriptive statistics and econometrics model, double hurdle)

- Location: Awi zone

- Duration: 2021

Activity: 3 Technical efficiency analyses in potato production 


\section{Methodology:}

- Sampling technique: This study will use multistage sampling to draw a representative sample.

- Data collection methods: Data collection will be done using a semi structured interview schedule and checklist (key informant interview)

- Methods of Data analysis: Both descriptive and econometric methods of data analysis will be employed. In this study, either Cobb Douglas or Translog stochastic production frontier model will be used based on generalized likelihood ratio test.

- Location: awi zone

- Duration: 2019/2020

\section{Expected deliverables}

- Some few genotypes will be identified for further evaluation and to release/registered as new varieties of potato by the end of 2021 and disseminate to farmers and other beneficiary.

- Planting depth, frequency of earthing up, of potato will be identified

- Determine appropriate potato agronomic practice and soil fertility enhancement mechanisms will be done by the end of

- Major potato diseases, insect pest, and weeds will be identified and recommend appropriate control measures

- Creating farmers who adopt improved potato technologies as well.

- Boosting potato value chain

- Number of potato stalk holder will be increased

- Cost-benefit analysis of potato production will be documented by the end of 2021 .

Benefits and beneficiaries: From this mega project, the livelihood of the society will be improved and enhanced. The beneficiaries of the project are, such as small-scale farmers, community based organizations such as farmers' cooperatives and unions, small, medium and large scale commercial farmers, seed growers, instructors, grain collectors and traders, BoA (at each level), NGOs, researchers, policy makers and students.

Technology dissemination plan: the result of this study will be reached to beneficiaries through reports, seminar presentations, workshops, proceedings, brushers, journals, field days, and workshops.

\section{Conclusion}

This mega project proposal of potato is agro-ecology oriented with the participation of different disciplines and it is very important for the improvement of the livelihoods of small scale potato producer farmers in Ethiopia. 


\section{Declarations}

Funding: N/A.

Compliance with Ethical Standards Conflict of interest: The author declare that no conflict of interest.

Consent to Participate: N/A.

Consent for Publication: I agreed to the submission of the manuscript for publication

\section{References}

1. FAOSTAT (Statistics Division for the Food and Agriculture Organization), (2015) Available online: http://faostat3.fao.org/faostat-gateway/go/to/

2. Scott G, Rosegrant M, Tingler C. (2000) Roots and tubers for the 21st century. Washington: International Food Policy Research Institute and International Potato Center.

3. Hirpa et al. (2016) Improving seed potato quality in Ethiopia: a value chain perspective. Wageningen: Wageningen Academic Publishers. p. 101-18.

4. CSA (Central Statistical Agency). Agricultural sample survey (2015/2016) Volume I, Report on Area and Production of Major Crops (Private Peasant Holdings, Meher Season). Statistical Bulletin 584. Addis Ababa, Ethiopia.

1. FAOSTAT (2016) Statistics Division for the Food and Agriculture Organization. Available online: http://faostat3.fao.org/faostat Statistical data. Accessed 08 October 2013.

2. Doss, C.R., Grown C., and Deere, C.D., (2008) Gender and Asset Ownership. A Guide to Collecting Individual-Level Data, Policy Research Working Paper, WPS 4704, Washington D.C. World Bank.

3. FAOSTAT (2010) The State of Food Insecurity in the World. Addressing food insecurity in protracted crises, Rome, Italy.

4. Bekele K, Eshetu B (2008) Potato disease management. In Root and tuber crops: The untapped resources, ed. Gebremedhin W, Endale G. Lemaga B. Addis Ababa: Ethiopian Institute of Agricultural Research. P. 79-96.

5. Gildemacher et al. (2009) Participatory Analysis of the Potato Knowledge and Information System in Ethiopia, Kenya and Uganda.

6. Hirpa et al. (2010) Analysis of seed potato systems in Ethiopia. Am J Pot Res. P. 537-552.

7. MOA. (2013) Strengthening National Capacity through Sustainable Increases in Agricultural Production and Productivity.

8. Cavatassi et al (2011) Modern variety adoption and risk management in drought prone areas: insights from the sorghum farmers of Eastern Ethiopia. Agricultural Economics. P. 279- 292.

9. EARO (Ethiopian Agricultural Research Organization) (2004) Directory of Released Crop Varieties and Their Recommended Cultural Practices. Ethiopian Agricultural Research Organization, Addis Ababa. 
P. 36.

10. Einstein, A., B. Podolsky, and N. Rosen (1935) Can quantum-mechanical description of physical reality be considered complete?, Phys. Rev. p. 777-780

11. Saied,M.M.; B. A. A. Zamil; G. M. El-Sanat and M. A. Abou El (2010) Effect of cultivation media, irrigation water sourses and organic manure leveles on yield of cucumber and tomato under protected greenhouses at north delta. J. Soil Sci. and Agric. Eng., Mansoura Univ. p.1145 - 1155.

12. Aleme Asresie and Lemma Zemedu (2015) Contribution of Livestock Sector in Ethiopian Economy. Advances in Life Science and Technology.

13. Fasil Reda (2006) Weed Management Research Experience in Ethiopia. Proceedings of Planning Workshop on "Facilitating the Implementation and Adoption of Integrated Pest.

14. Beza (2014) Who Saved the Forest of Ethiopia, One Church at a Time, a Conservation Story.

15. Ilangantileke S.G., Kadian M.S., Hossain M., Hossain A.E., Jayasinghe U., and Mahmood A.A. (2001). Toward Alleviating Poverty of Rural Potato Farmers by Strengthening the Potato Seed System in Bangladesh: A Rapid Rural Appraisal.

16. Lung'aho, C., B. Lemaga, M. Nyongesa, P. Gildermacher, P. Kinyale, P. Demo and J. Kabira (2007) Commercial seed potato production in eastern and central Africa. Kenya Agricultural Institute. P. 140.

17. Zelalem, A., Tekalign, T.and Nigussie, D (2009) Response of potato (Solanum tuberosum L.) to different rates of nitrogen and phosphorus fertilization on vertisols at DebreBerhan, in the central highlands of Ethiopia. Afr JPlant Sci. p. 16-24.

18. Bonier bale, M., de Hann, S. and Forbes, A (2013) Procedures for standard evaluation trials of advanced potato clones: An International Cooperators' Guide. International Potato Centre (CIP). The influence of farmer demographic characteristics on environmental behaviour: A review. Journal of Environmental Management. R.J.F. P. 124.

19. Kleinkopf, G.E., Westerman, D.T and Dwelle, R.B (1981) Dry matter production and nitrogen utilization by six potato varieties. Agronomy Journal. P. 799-802.

20. SAS Software Syntax, Version 9.4. SAS Institute Cary, NC, USA.

21. CIMMYT (1988) from Agronomic Data to Farmer Recommendations: An Economics Training Manual. Completely revised edition. Mexico. D.F. 